Why do the deads speak?

Uma leitura de Eros e Thanatos no romance de Filipa Melo $A$ reading of Eros and Thanatos in the novel by Filipa Melo

\title{
Alessandra Leila Borges Gomes
} Fernandes (Állex Leilla)*

Universidade Estadual de Feira de Santana

Bruna Souza Rocha Oliveira**

Universidade Estadual de Feira de Santana

*Doutora em Estudos Literários e professora Adjunta da Universidade Estadual de Feira de Santana. E-mail: allexleilla@gmail.com.

**Mestranda do Programa de Pós-Graduação em Estudos Literários da Universidade Estadual de Feira de Santana. E-mail: brunabruuna@ hotmail.com. 
Resumo: A partir das noções de literatura e experiência de morte, conceitos extraídos de Phillipe Ariés e Maurice Blanchot, analiso a história que é tecida no romance Este é o meu corpo, de Filipa Melo, que aborda a relação de Thanatos e Eros, mitos gregos definidos por Sigmund Freud como pulsão de morte e pulsão de vida. Movimentando-se entre pequenas narrativas, que funcionam como um mosaico de memórias, costumes, amorpaixão, violência contra a mulher, entre outras agudezas da condição humana, a autora portuguesa desenvolve no romance - cujo título remete à homília católica da eucaristia - um personagem-chave para elucidar o crime. Trata-se não de um detetive oficial, mas de um narrador médico-legista, que, no processo de autopsia, vai desvendando as circunstâncias da morte da personagem Eduarda, a fim de devolver a identidade da vítima: uma mulher jovem, encontrada morta e desfigurada numa praia. Contraditoriamente, ao tentar revelar como se deu esse assassinato, o labor da autópsia permite que o corpo sem vida fale. Nesse sentido, compreendo que o médicolegista é a metáfora da própria literatura, no seu trabalho incessante, a nos conduzir à dimensão em que Eros e Thanatos se enfrentam e se mesclam, enquanto o corpo irreconhecível da moça é a realidade, matéria disforme e permeada de signos, a nos pedir leitura, tradução, forma, representação.

Palavras-chave: Eros; Thanatos; representação literária; literatura portuguesa contemporânea; Filipa Melo.

Abstract: From the notions of literature and the experience of death, extracted concepts Phillipe Ariès and Maurice Blanchot, I analyze the story that is woven in the novel This is my body, by Filipa Melo, focusing on the relationship of Thanatos and Eros, Greek myths defined by Sigmund Freud as the death drive and the life drive. Moving between small narratives, which act as a mosaic of memories, customs, love, passion, violence against women, among other sharpness of the human condition, the Portuguese author develops in the novel - - whose title refers to the Catholic homily of the Eucharist - a key character to elucidate the crime. He is not an official detective, but a medical-forensic narrator who, in the autopsy process, goes unraveling the circumstances of the death of the character Eduarda, in order to return the identity of the victim: a young woman, found dead and disfigured on a beach. Contradictorily, to try to reveal how was this murder, the labor autopsy allows the lifeless body talk. In this sense, I understand that the coroner is the metaphor of literature itself, in its incessant work, to lead us to the dimension in which Eros and Thanatos face each other and are mixed, while the girl's unrecognizable body is reality, shapeless matter and permeated with signs, to ask us for reading, translation, form, representation.

Keywords: Eros; Thanatos; literary representation; Portuguese contemporary literature; Filipa Melo..

Recebido em 13 de julho de 2018

Aprovado em 25 de novembro de 2018

FERNANDES, Alessandra Leila Borges Gomes, OLIVEIRA, Bruna Souza Rocha. Por que os mortos falam? Uma leitura de Eros e Thanatos no romance de Filipa Melo. Légua \& Meia, Brasil, n. 9, v. 1, p. 242-259, 2019. 
Lançada em Portugal em 2001, mas só publicada no Brasil em 2004, a narrativa de Este é o meu corpo traz fragmentos de subjetividades diversas que emergem a partir de um fato grave: o corpo desfigurado de uma mulher é encontrado numa praia. Esse acontecimento nos conecta aos fragmentos de vida dos outros personagens do livro, que vão desfiando suas impressões, ações, rotinas, preconceitos e crenças diante da ruptura imposta pela morte. É o primeiro romance de Filipa Melo, jornalista e escritora de língua portuguesa, nascida em Cuíto, município de Angola, outrora denominado de Silva Porto. Além de Este é meu corpo, objeto de análise deste artigo, Melo é autora de Os últimos marinheiros (2015) e Dicionário sentimental do adultério (2017).

A praia, cenário onde o cadáver irreconhecível da vítima é encontrado, nos remete para a simbologia dos portugueses com o mar, bem como para Os últimos marinheiros, livro fruto de um trabalho jornalístico da autora, cuja voz se mistura às vozes dos homens e mulheres lusitanos que têm no mar seu principal sustento e que, em nossos dias, estão ameaçados de extinção. "O mar chamou-me desde que me lembro. Mas sei que não lhe pertenço. O mar tanto oferece, tanto ruge, segundo leis desconhecidas", ressalta a escritora nesse ensaio (MELO, 2015, p.9), apontando para uma das grandes preocupações éticas da contemporaneidade: encontrar uma forma de conviver simultaneamente com os diferentes modos de vida, em vez de provocar seu desaparecimento.

É de uma oferta ou bramido do mar que surge o corpo violentado e sem vida de Eduarda, personagem que impulsiona toda a narrativa de Este é meu corpo. O cadáver encontrado na praia é a metáfora do trabalho exaustivo do escritor em seu atrito com o mundo em sua eterna busca de conhecimento. De forma mais abrangente, é o labor da própria literatura, que se dá num contínuo paradoxal da dinâmica da vida, em que as coisas ou seres precisam ser recortados para que apreendamos o fundamento deles e, partir dessa apreensão, possamos aprofundá-lo e ampliá-lo, pondo em relevo sua complexidade infinita. Segundo Olavo de Carvalho, em Aristóteles em nova perspectiva (2006), o processo de recortar o mundo, para melhor analisá-lo, faz com que a literatura produza uma abstração conceitual, tornando criativo o algo recortado. Para o filósofo brasileiro, tal é o mecanismo mental do ser humano para adquirir e produzir conhecimento: recortar o mundo para, a partir de uma abstração, imaginar o que falta, o que poderia ter acontecido e/ou pode acontecer.

Mais do que imitar o possível (como mostra Aristóteles e, derivado dele, Auerbach, Barthes, entre outros), a literatura dá uma forma estética e memorizável a esse possível, permitindo que o concebível possa ser (re)contado e diga aos ouvidos do mundo tudo aquilo que não sabíamos ou apenas intuímos dele, mas, até então, não podíamos expressar. Carvalho considera que esse jogo mental da literatura (ao qual ele denomina de concepção) é necessário para se produzir pensamento próprio em qualquer área, pois é, muito além de uma mimese ou criação artística, o verdadeiro método para se movimentar entre o ideal e as variedades infinitas. Nessa perspectiva, o escritor é aquele que tem consciência da complexidade dessa operação mental, sabe que fatos e imaginação não são duas instâncias isoladas, mas interfaces do conhecimento. Para Carvalho, a mimese literária não apenas imita o real ou suas possibilidades de existência, ela é, antes, uma tecnologia humana que busca o equilíbrio entre objeto material (realidade) e objeto formal (criação), sendo, em síntese, um método que revela a própria capacidade mental dos seres humanos de adquirir e produzir conhecimento. Além disso, como a literatura necessita da coautoria de seus leitores - que ampliarão os signos dispostos na página pelo escritor - , ela nos força à criação incessante de imagens, levando a caminhos de compreensões e saberes muitas vezes distintos daqueles previstos e/ou manipulados pelo autor. Em outras palavras, a literatura bem sabe que o fato concreto não tem limites nem 
formas, contudo, para que exista plenamente na dimensão humana qualquer fato relevante precisa de um acabamento, uma feitura, que o torne, a um só tempo, singular e plural aos nossos sentidos, e, assim, possa nos ensinar algo acerca do mundo e de nós mesmos.

Metaforizando o processo de criar realidades possíveis através do labor com a matéria disforme da vida, o relato do médico-legista de Este é o meu corpo nos convida a conhecer o mosaico perdido, mas subjacente, do qual Eduarda foi tirada: o filho que ela acabou de dar à luz, mas não poderá criar; a relação cheia de arestas com o pai (dela); seu caso com um homem casado (pai da criança); os investigadores do crime e os outros legistas; a esposa de seu amante; entre outros personagens que a rondam. Como num ciclo novelístico, o corpo da vítima leva à descoberta do crime, que aponta para possíveis réus, que remetem a seus álibis e/ou culpabilidade, que deixam dúvidas e lacunas acerca do verdadeiro culpado, como numa trama policial. Mas não é a atmosfera da investigação de um assassinato que salta aos olhos do leitor, e, sim o trabalho dialógico do médico-legista, um dos narradores mais presentes no romance que, ao estabelecer uma conversa íntima com o corpo prenhe de signos da moça, expõe a agudeza da relação entre Eros e Thanatos.

No pensamento mítico grego, Eros está relacionado ao amor, enquanto Thanatos incorpora a morte. Numa das versões do mito, Eros adormece numa caverna depois de ser embriagado pelo irmão de Thanatos, Hipno (deus do sono). Ao adormecer, Eros, o cupido que flechava homens e mulheres - jogando-os na dimensão traiçoeira do amor - , deixa cair suas flechas, que se misturam às de Thanatos, guardadas na mesma caverna. Ao acordar, o deus do amor recolhe algumas dessas flechas contaminadas, sem perceber que não eram as suas (BRANDÃO, 1995). Esse episódio fabuloso seria a razão porque amor e morte estão imbricados, numa relação ambivalente que não se reduz à constatação de duas polaridades, mas, antes, nos chama atenção para o amálgama de suas existências e seus campos de ação: a flecha do amor está, desde o princípio, misturada à da morte.

De modo geral, na tradição dos estudos e das representações acerca do amor no mundo ocidental, é possível diferenciarmos três tipos ou formas mais usuais que orientam sua delimitação: a forma Eros ou amor-paixão, a forma Philia ou amor amigo, e a forma Ágape ou amor universal, também chamado de Caritas (SPONVILLE, 1999). Eros ou amor-paixão está relacionado com a idealização do outro, uma demanda sentida pelo amante de que o ser amado possui a chave ou resposta para o seu problema, o remédio para sua ferida, a solução para o seu vazio, enquanto a forma Philia implica um amor entre parceiros que estão em pé de igualdade, e Ágape constitui o amor desinteressado, distribuído a todo e qualquer ser vivo, independentemente de qual papel ele tenha em nossa vida - é o amor fino ou puro, definido por Padre Antônio Vieira como o amor legado por Cristo à humanidade.

Diferente da forma Ágape, o amor-paixão se orienta, sobretudo, pelo desejo daquilo que não se tem, pela vontade de complementação, de encontrar alguém a quem se credita o poder de revelar o sentido maior da vida - é o que no senso comum chamamos de crença no amor romântico. Essa orientação pela procura da alma gêmea, do par perfeito que precisa ser encontrado pelos sujeitos em suas trajetórias de vida é uma das marcas da experiência do amor-paixão. Antes mesmo que os sujeitos vivenciem uma relação amorosa, já estão em contato com a representação ideal dela e com os mecanismos que a viabilizariam - como rituais e lugares de procura, investimentos na aparência e no comportamento, formas de conquista e todo um arsenal de técnicas em prol de encontros que efetivem tal experiência.

A preparação para o encontro com o grande amor é, desde a época clássica, um elemento importante na conquista amorosa, mas não o único, uma vez que a sorte e o destino também coexistem em tal concepção, embora se possa tirar proveito delas de 
maneira inteligente e racional, através de uma técnica, conforme ensina Ovídio, logo no início de sua $A$ arte de amar:

É graças à arte que os barcos podem avançar rapidamente, impelidos pela vela e pelo remo, é graças à arte que pode avançar o carro veloz. Também o Amor deve ser governado pela arte.[...] Embora ele seja rude e muitas vezes me resista, é ainda criança [o Amor, Eros ou o Cupido], sua idade é tenra e deixa-se dirigir. [...]Antes de mais nada, trata de encontrares o objeto amado, tu que és um soldado que terças armas pela primeira vez; em seguida, dirige teus esforços no sentido de conquistares a mulher preferida e, em terceiro lugar, procura fazer com que teu amor dure longo tempo. Tal é o método; dentro desses limites, o nosso carro deixará marcado o sinal de suas rodas, a toda velocidade, para alcançar a meta. [...] Ela [a mulher preferida] não te cairá nas mãos trazida pelas auras; terás de procurá-la com teus olhos. (s/d, p. 23-25).

Para Ovídio, Eros inclui a crença de que o amor é a soma de um aprendizado: para saber gozá-lo, há de se adquirir um método antes (na procura do ser amado), durante (no ato da conquista) e depois (no prolongamento do êxtase da conquista). O método é racional e controla a emoção. O canto de Ovídio é um manual de fórmulas e atitudes diante da experiência amorosa, o que mostra o amor, tanto no mundo dos deuses quanto no dos homens, como uma força maior ligada à embriaguez dos sentidos, ao acúmulo de aventuras, à disposição constante aos prazeres carnais. $\mathrm{O}$ texto foi escrito numa época tão em ruínas a ponto de Ovídio ser chamado tantas vezes de poeta da decadência romana. Em $A$ arte de amar, o poeta romano investe na aproximação de Eros com Dionísio, misturando idealização e sexo. Seu poema traça um mapa de todos os lugares onde o macho deveria ir encontrar a fêmea para o banquete do amor - o Pórtico de Pompeu, os teatros recurvados, as praças públicas, a corrida de cavalos no circo, as festas de Baco , assim como a maneira com que os homens deveriam se vestir e se portar em público. $\mathrm{O}$ amor é representado como o maior dos prazeres, aquele que merece ser degustado à exaustão e de maneira livre, sem compromissos, sem limites.

Em Ovídio, as ações tomadas diante de Eros devem ser racionais, levando muito mais ao espaço dionisíaco do que à idealização: o amor-paixão é o maior de todos os prazeres que o ser humano pode gozar no mundo, por isso, há de se aprender a usufruir desse banquete de forma variada e cada vez mais. No entanto, cada linha de $A$ arte de amar, mesmo sem querer, aponta para o que se quer evitar a todo custo: que a face contaminada de Eros, seu limiar fronteiriço com Thanatos, se sobreponha e mergulhe os amantes no caos, na morte, no fim.

Na cultura greco-romana, o deus Eros, também chamado de Cupido ou Criança, é temido tanto pelos humanos quanto pelos deuses, pois ninguém consegue escapar de sua ação sem experimentar dor, perturbação, angústia. Essa relação mitológica guarda um paradoxo, uma vez que Eros é, a um só tempo, o que se procura e o que se evita, seu mito engendra a impossibilidade do ser humano de controlar conscientemente essa força ou pulsão, mas, também, mostra nossa busca incessante por esse controle. O canto de Ovídio é, justamente, a tentativa de controle, de racionalização dessa força: "quanto mais o Amor me fere, quanto maior é a violência com que investe, melhor poderei vingar-me das feridas que ele me fizer" (OVÍDIO, s/d, p.24). O método consiste então em enfraquecer a flecha do Cupido, tornando-se em vez de vítima um eterno caçador de presas amorosas. É a crença de que estando o sujeito constantemente praticando os jogos amorosos (na arena do amor), dominando os mecanismos de conquista, ele evitará, assim, ser surpreendido pela captura do Amor. Aqui, o excesso é a cura, pois a única forma de dominar Eros é não evitá-lo, mas, antes, transformar sua presença num banquete. Séculos 
depois, Ian Watt (1999) compreenderá que essa mesma concepção do amor-paixão alimenta a performance do Don Juan, analisado pelo autor como um dos quatro mitos do individualismo moderno ${ }^{1}$.

Se para Ovídio é preciso evitar que Eros seja uma experiência dolorosa - de perda de si mesmo, de reconhecimento de incompletude, de necessidade do outro, de medo da rejeição, de entrada no desconhecido - , para outras representações ocidentais o Cupido simboliza a mistura de luz e escuridão, de que nos fala Dante, séculos depois, guiado por Beatriz, ou a junção de vida, veneno e morte (como ocorre em Tristão e Isolda, Romeu e Julieta, Abelardo e Heloísa, Paola e Francesco, entre tantos outros pares trágicos). A contaminação entre as flechas de Eros e Thanatos nos remete também ao paradoxo do amor, presente no discurso de Sócrates, quando menciona seu aprendizado, acerca de Eros, com Diotima.

No registro que Platão faz dessa lição socrática, no Banquete, vemos que o amor não é composto de beleza e completude, pois a pessoa ama o que ela gostaria de possuir (aquilo que lhe falta), sendo, portanto, Eros destituído de beleza própria mas belo em potência. Porém, Sócrates acrescentou que essa destituição de beleza inicial não faz o amor ser feio, mostrando que em vez de uma oposição excludente o que temos é uma mediação: Eros como uma ponte, um intermediário entre os deuses e os seres humanos, e também entre beleza e feiura, miséria e riqueza, luz e treva etc., pois, segundo o discurso de Diotima, apreendido pelo filósofo, o objetivo do amor é a criação, uma criação que o leva à imortalidade, sendo Eros eternamente oposto a Thanatos, pois esse último impulsiona o caos e a destruição.

Por sua natureza complexa e contraditória, Eros é descrito pelos estudiosos da cultura greco-latina como uma das divindades primordiais, devido a uma posição privilegiada no Panteão dos Deuses (VERNANT, 2000), embora também seja classificado como um mito da natureza, assim como Orfeu, Arion, Narciso, Eco, Psiquê, entre outros (EVSLIN, 2004). Em Hesíodo (Teogonia), Eros vem depois de Caos, Gaia (Terra) e Tártaro, como "o mais belo dos deuses imortais" (1995, p.116). Nas diferentes versões sobre sua origem, ora o Cupido está relacionado com o princípio cósmico, ora é associado à beleza de sua mãe Vênus (Afrodite) ${ }^{2}$, ora é uma junção das qualidades e defeitos de Pênia (a pobreza) e Poros (Recurso, filho de Prudência) - conforme destaca Sócrates, no discurso de Diotima. Em o Banquete, são destacados três aspectos fundamentais de Eros: primeiro, a separação do bom e mau Amor, presente no discurso de Pausânias; depois, seu caráter andrógino, recontado na fala de Aristófanes; e, por fim, esse lugar limítrofe, explicado a Sócrates por Diotima, ou seja, a eterna dança de Eros entre coisas de natureza opostas, sua carência que o faz nem mortal nem imortal, nem feio nem belo, nem bom nem mau, nem sábio nem tolo, mas uma ligação invisível entre o mundo dos homens e o mundo dos deuses.

\footnotetext{
${ }^{1}$ Os outros mitos analisados por Ian Watt, em Mitos do individualismo moderno, são Dom Quixote, símbolo do abismo entre subjetividade e ordem objetiva; Robinson Crusoé, que metaforiza a procura dos homens e mulheres modernos pela mítica integração com a natureza; e Fausto, que aprofunda as relações entre Bem e Mal.

${ }^{2}$ Numa versão Afrodite é filha de Zeus e de Dione; noutra ela teria nascido dos órgãos sexuais de Urano, que foram cortados por Cronos e, ao caírem nas águas salgadas do mar, deram origem à deusa do amor; numa outra versão, Vênus nasce da própria espuma do mar. De qualquer forma, a ela são atribuídos à capacidade humana de materializar o amor no ato sexual, a capacidade de reconhecer a beleza desse ato, a perspectiva de fertilidade oriunda dele, e o sentimento de vingança e de raiva ou irritação, de morte e destruição que também ocorrem no amor. Esses aspectos negativos advêm da origem complexa e do temperamento irritadiço de Vênus, que usava seu cinto mágico ou fita bordada ("kestós", no grego) para inspirar o desejo carnal no belo (BRANDÃO, 1995; VERNANT, 2000; EVSLIN, 2004).
} 
Segundo Salvatore D’Onofrio (2005), Eros representa a força de "coesão interna do Cosmos", seu mito "é a possibilidade de uma continuidade da vida na Terra", mesmo dividida entre carne e espírito, matéria e divindade, sabedoria e ignorância (pobreza). D’Onofrio remete para a compreensão que Platão possuía desse mito: uma espécie de dáimon ou mediação entre o mundo celestial e o mundo humano. Tal mediação foi perdida diante da redução de Eros ao aspecto carnal, e sua confusão com o deus do sexo e da procriação (Priapo) fez nascer alguns usos para a palavra que já não remetem ao mito grego, como ocorre com o emprego cotidiano da palavra "erotismo", por exemplo. Isso vai ser agravado pela impossibilidade de junção entre corpo e alma trazida por muitas representações do amor romântico. Essas representações, muitas vezes, consideram contraditória a união do divino com o carnal, seja porque desejam expor ora a supremacia do espírito, ora a da matéria (no caso das representações realistas), seja porque a comunhão desses dois aspectos ao longo das histórias dos sujeitos foi se repetindo, engendrando clichês. Por isso, em vez de mediação entre espírito e matéria, muitas vezes o que encontramos nas representações de Eros é a ênfase no amor contemplativo e idealizado - como no amor cortês e no ultrarromantismo - , ou o amor sensual, que destaca o aspecto corporal, a satisfação ou prazer (à maneira de Ovídio, em $A$ arte de amar). Essas construções, no entanto, não escondem a dificuldade humana de lidar com a complexidade de Eros, pulsão de vida, que se movimenta sempre na fronteira de Thanatos, da ameaça do fim.

No universo freudiano há o amor transferencial (na busca da verdade de si mesmo e na ignorância desse saber, o analisando ama o analista, e esse amor abre um espaço onde o paciente recria suas próprias possibilidades de existência) e o amor cotidiano (em que Eros é visto como uma pulsão de vida, o estímulo que tece uma rede de relações entre núcleos individuais e organismos maiores, numa atividade vital incessante). O percurso de Freud foi o de uma compreensão da sexualidade humana, mas como essa caminha de braços dados com o amor, ao inserir o sexual no registro do pulsional, ele inscreveu também em ambos (amor e sexualidade) a impossibilidade de satisfação, isto é, a ideia de que o ser humano só consegue se satisfazer fora da realidade, no campo da fantasia.

Dessa forma, tanto o amor quanto o sexo são buscados na vida diária, nos discursos, nos gestos, nos corpos humanos. Eros é como que uma síntese de tudo que pode ser traduzido como energia (libido), que compreende o amor aos pais, a si mesmo, aos filhos, às pessoas em geral, ao conhecimento, às abstrações, às coisas. Nessa energia estão tanto as pulsões ${ }^{3}$ (de afeto), quanto o ciúme, a inveja e os desejos sexuais: "O amor é, assim, apresentado como uma ampliação do conceito de sexualidade e ao mesmo tempo ancorado na inadequação radical dos objetos à satisfação sexual, vinculada a um fator de desprazer inerente à sexualidade humana" (VALDIVIA, 1993, p.4).

No discurso freudiano, se destaca como aspecto principal dessa busca incessante de amor o desejo de ser amado, que, tal como o sexo, é impossível de ser satisfeito. Uma das narrativas que tentam explicar tal busca é o mito do andrógino, contado por Aristófanes, no Banquete. Ele relata que antes de serem reduzidos a dois gêneros, os seres humanos se dividiam em três: masculino, feminino e andrógino. $\mathrm{O}$ andrógino possuía, ao

\footnotetext{
${ }^{3}$ Pulsão, segundo Freud, é "o representante psíquico de uma fonte endossomática de estimulação que flui continuamente, para diferenciá-la do “estímulo', que é produzido por excitações isoladas vindas defora”. É um dos conceitos da delimitação entre o anímico e o físico: "A hipótese mais simples e mais indicada sobre a natureza da pulsão seria que, em si mesma, ela não possui qualidade alguma, devendo apenas ser considerada como uma medida da exigência de trabalho feita à vida anímica. $\mathrm{O}$ que distingue as pulsões entre si e as dota de propriedades específicas é sua relação com suas fontes somáticas e seus alvos". Cf. FREUD, v. VII, p. 102-3 (versão em CD-ROM).
} 
mesmo tempo, as características de macho e fêmea, tinha uma enorme força e resistência, além de ser muito ambicioso. A ambição leva-o a exortar os outros para escalar os céus, conspirando contra os deuses. Ofendidos, os deuses decidem extinguir a espécie humana com um raio. Porém, voltam atrás ao perceber que junto com os seres humanos iriam ser perdidos, também, os sacrifícios de devoção às divindades e as exaltações. Zeus então opta por partir os três seres ao meio, não apenas enfraquecendo-os, mas os tornando incompletos. Dessa divisão mítica nasceria o eterno desejo de encontrarmos nossa outra metade no mundo.

Em oposição a Eros está Thanatos, como uma força contrária à vida, uma pulsão de morte. Quem é visitado por Thanatos fica congelado no tempo e no espaço. Trata-se, também, de subjetividades que caem numa imobilidade, inaptidão para o cotidiano, desintegração da individualidade, ou numa espécie de indiferenciação no Cosmos - o que leva à anulação de si mesmo, à autodestruição.

Thanatos também é uma das divindades primordiais da mitologia grega, filho de Nix (a Noite), e irmão gêmeo de Hipnos (o Sono), foi concebido na cultura ocidental como o maior inimigo dos seres vivos, sobretudo dos humanos, que guardam um ódio imenso por Thanatos, em razão de sua figura representar a violência do corte, da perda. Por isso, é simbolizado muitas vezes com um rosto cadavérico, coberto por um véu, ou por um esqueleto, portando uma foice numa das mãos, ou, ainda por asas, que simbolizariam a crença noutra dimensão da existência. Alguns historiadores lembram que mesmo a pronúncia do nome de Thanatos costumava ser evitada na Grécia (BRANDÃO,1995; VERNANT, 2000), devido ao medo de que o verbo atraísse esse deus, convidando-o a espalhar a perda e a destruição sobre quem o invocasse. Em Hesíodo, Thanatos prostra-se diante da porta dos Infernos, o que ressalta sua condição limítrofe entre mundo dos vivos e mundo dos mortos, e mostra que ambas as dimensões não se encontram tão dissociadas assim, pois há uma espécie de fronteira invisível formada tanto pelos elementos comuns quanto pelo que há de diferente entre elas.

Um aspecto que aproxima Eros de Thanatos é a inclinação para uma integração do Eu no Todo. Como pulsão de vida, Eros impele todos os organismos a repetir o movimento original (estado primevo) de busca de união/retorno à totalidade, no entanto, na pulsão de vida cada elemento conserva sua individualidade, enquanto que na pulsão de morte os limites que diferenciam uma individualidade da outra desaparecem, ou seja, Eros leva à soma, Thanatos leva à subtração.

Essas noções antagônicas, trabalhadas por Freud em Além do princípio do prazer, revelam muito mais um jogo entre pulsão de vida e pulsão de morte do que uma exclusão ou mesmo a presença pura de uma delas no indivíduo. Ao contrário, enquanto a última alimenta o instinto de destruição, a outra incita a evolução pessoal. Dessa forma, ambas podem ser flagradas na esfera prática da vida humana, ora desenvolvendo a autoestima, ora lançando o sujeito num mar de insatisfações. É bom lembrar que essa característica de ser uma força inquieta e insatisfeita sempre fez parte das naturezas conflituosas de Eros e Thanatos, conforme apontam Platão (Banquete), Hesíodo (Teogonia) e Ovídio (As metamorfoses), entre outros, e é mais por espírito didático que Freud tenta explicar essas duas forças a partir de seus contrastes, uma vez que a ele interessa conhecer, definir e separar os instintos de autopreservação e preservação da espécie (Eros) daqueles de anulação e destruição (Thanatos).

Também em $O$ mal-estar na civilização, Freud ressalta que Eros configura nosso instinto de vida, enquanto Thanatos age potencializando os aspectos negativos da sobrevivência, a sombra, a decadência, o caos, modulando nosso instinto (inconsciente) de destruição. Não à toa, a observação freudiana, sobre ser a morte o objetivo de toda 
vida, diz muito da tragicidade com que nos movemos: vivos para morrer, e, quando mortos, querendo viver em quem permanece.

É esse jogo complexo que vemos ocorrer na narrativa de Filipa Melo: enquanto o bisturi do legista devassa o corpo da vítima, revelando a causa de sua morte violenta, os olhos do médico reagrupam detalhes colhidos pela análise das unhas, dos dentes, dos cabelos, dos tecidos, do sangue, das vísceras, dos órgãos, nos fazendo conhecer manias, hábitos e tudo mais que permeia uma vida humana. Paradoxalmente, a moça morta está a nos dizer muito a respeito daquilo que não esmorece, tampouco se cala, em nossa matéria. Os mortos falam?, pergunta o personagem, para logo adiante responder: Dentro do corpo, encerramos várias, múltiplas dimensões do mesmo "eu” (MELO, 2015, p.88).

No ensaio Este é o meu corpo que é dado por vós: sacrifício e redenção na obra de Filipa Melo, Dayane Rose Fraga Lima destaca a importância do médico legista enquanto investigador do crime, que, no entanto, não se restringe à descoberta da causa da morte da vítima, mas, antes, atua numa zona de escuta sutil, estabelecendo com Eduarda um contato "imprevisível, profundamente afetivo":

Sua investigação não se dá fora, além ou nas imediações do corpo, seus interrogatórios não se dirigem às testemunhas ou suspeitos, mas partem sempre dos gestos de leitura silenciosa, respeitosa e atenta do cadáver à sua frente. Esta tarefa inglória acaba por determinar entre ele e ela um contato imprevisível, profundamente afetivo. Não na direção degenerada da necrofilia, [...], mas na direção inusitada da reformulação filosófica e política do problema posto pelo romance policial ao leitor contemporâneo. Filipa Melo, ao contrário da maioria dos escritores desta linha, não vê como objetivo principal de sua história o desvendamento de um espírito maníaco e extraordinariamente inteligente, que precisa ser afastado da sociedade e penalizado por suas ações. Seu objetivo é tentar refazer os caminhos que terão conduzido a pessoa que resta morta a tão trágico desfecho, analisando algumas possibilidades pelas marcas deixadas impressas em seu corpo. (LIMA, 2015, p.17).

Dayane Fraga Lima expõe a percepção crítica da romancista que implica uma quebra na expectativa da trama policialesca, indicando questões ainda mais cruéis do que o assassinato da moça, como a falta de alegria e amor com que a personagem vivia, antes de ser morta. Esses elementos de ordem menos objetiva são lidos durante a necropsia que, a despeito de ser uma atividade técnica e detetivesca, no olhar de Filipa Melo ganha contornos mais profundos, conforme enfatiza Lima:

O "diálogo", portanto, acontece entre o médico e o cadáver. Um diálogo em discurso indireto livre, ocorrido em reflexão, como numa telepatia. $\mathrm{O}$ corpo não é algo meramente descartável. É o que resta de "alguém"; continua a fazer parte deste alguém. É um depoimento vivo, confissão e denúncia, relato, enredo, receptáculo da memória. Apesar de muito machucado, destruído, destituído de seu aspecto original, não é repulsivo. Repulsivo, neste romance, é o ato de matar - o que não é diretamente percebido no gênero convencional, apesar dos julgamentos e condenações impostos pelo sistema social e reproduzidos na trama. Repulsivos são os instintos do mal, da indiferença, do desamor, da ignorância, que não têm corpo, mas que penetram corpos que lhes dão guarida. Como diz Filipa, a brutalidade dos sentimentos abstratos supera muito a fragilidade dos corpos concretos, que acabam por não suportá-la. Morremos todos, de um jeito ou de outro, do coração. Por excesso ou falta de amor. (LIMA, 2015, p.17). 
De dentro de Thanatos, Eduarda fala e sua voz emerge de um espaço complexo, por onde nos faz compreender que, quando viva, era morta dia a dia por todos aqueles que minavam sua vitalidade. Mais do que nos remeter para as narrativas que, à maneira de Machado de Assis, são construídas na discursividade de um sujeito morto, que falam de si no além-túmulo, Este é o meu corpo nos convida a sermos intérpretes dos sinais de um discurso dilacerado pela violência dos maltratos diários, ou seja, Eduarda não narra, mas impõe ao narrador a urgência de ouvir e traduzir sua história de dor e privação.

Além de ser um dos maiores mistérios da existência humana, a morte é nossa única certeza. Podemos antecipá-la através de tiro, veneno, overdose, automutilação, enforcamento, gás de cozinha, inanição, depressão, obsessões, queda livre, maus hábitos, vícios, entre tantas outras formas de suicídio, porém, só podemos escolher se queremos viver ou não viver em certas circunstâncias - não nos foi dada a escolha de não morrer nunca. Enquanto seres que sabem que vão morrer, buscamos, diariamente, evitar tal acontecimento, por sabermos que se trata de uma força cujo corte é definitivo, impossível de ser desfeito e de natureza incompartilhável. Podemos apenas dividir a dor, o vazio, o desejo, a saudade ou a indiferença provocadas pela morte de outrem, mas não é possível ofertar ao outro o que sentimos durante nossa travessia para o além. E é justamente por ser a experiência humana mais desprovida de retorno, meio termo, reversão e partilha, que a morte impõe sua presença instigadora nas produções artísticas e literárias.

Philippe Ariés, em História da morte no ocidente, aborda os aspectos diacrônicos, sincrônicos, simbólicos e culturais que permeiam a nossa relação com a morte. Em cada época, o autor busca elementos peculiares que vão formando uma visualidade densa acerca de como homens e mulheres lidam com a ideia do fim - de si mesmo e do outro. Da imagem da morte domada, na Antiguidade, quando falecer é visto com uma etapa natural da evolução e as pessoas tratam de ler os signos que anunciam o fim, até o século XIX, vemos que a morte deixa de ser um ritual público e simples — porém aceito pelo moribundo e seus familiares - , e vai ganhando outros contornos, como o culto aos mártires - quando a proximidade com os corpos enterrados daqueles que morreram bravamente passa a ser cultivada — e, mais tarde, o fenômeno da individualização, que desnaturaliza e dessocializa a morte.

História da morte no ocidente propõe um processo lento, no qual representações coletivas e tendências subjetivas são lidas no intuito de se compreender certas transformações, ocorridas por volta do século XII, que introduziram na relação do homem ocidental com a morte o apego exacerbado de sua própria biografia ou trajetória. Esse tomar consciência de si mesmo é exemplificado por Ariès com a mudança dos sepulcros coletivos para os individuais. Nesse processo, ele também analisa as figurações estéticas da morte nas artes e na literatura, mostrando que a partir dos século XVI, a crueldade, o mórbido e o violento tomam o centro das representações, delineando, sobretudo, o sofrimento - de quem parte, de quem fica. Essa dor vai sendo, gradativamente, evitada, desviada, pelas novas gerações, num processo denominado pelo teórico de hedonismo moderno, no qual se procura, acima de tudo, não se pensar nem na nossa morte, nem da de quem amamos.

Nos nossos dias, um dos indícios mais fortes de que nossa relação com a morte tornou-se estranha é o pensar quase calado de que, se não podemos vencê-la, devemos ao menos retardá-la. Esta parece ser a primeira assertividade da morte: não apenas é irrevogável, mas é preciso aprender a conviver com sua ameaça constante. Contudo, aprender, na nossa época, passou a significar evitá-la. Trata-se de uma contradição: somos seres conscientes da nossa morte e da do outro, mas, ao mesmo tempo, somos aqueles 
que mais as querem esquecê-las. É, portanto, imperativo tentar não permanecer muito tempo aí, nesse espaço de perscrutação da morte. É preciso fugir, seja para ganhar tempo, adiando a nossa hora derradeira, como em As mil e uma noites, seja para evitar a dor da perda de quem amamos, como no conto Nada de novo na frente ocidental, de Lygia Fagundes Telles, no qual a personagem, incapaz de lidar com a ideia da orfandade, desenvolve um jogo mental de postergar o momento em que atendeu ao telefone e recebeu a trágica notícia da morte do seu pai. Nesse caso, adia-se o real através do verbo, reeditando o confronto para enfraquecê-lo.

A tendência em não pensarmos na tragicidade de nosso destino parece estar entranhada na contemporaneidade, tal qual uma máxima coletiva absorvida por osmose. Recordo-me de quando minha afilhada, à época com cinco anos de idade, tomou consciência da morte: andávamos pelas ruas do Santo Antônio, em Belo Horizonte, quando nos deparamos com um passarinho agonizando no meio fio. Ela agachou-se e pôs-se a falar com o bicho, a perguntar, na espontaneidade das crianças, se ele estava doente, com fome, onde estava a mamãe dele. Eu tentei tirá-la dali, chamando-a para irmos embora. Para mim, a única preocupação era que ela não tocasse o animalzinho ferido - podia passar alguma doença ou ele poderia reagir de forma agressiva ao toque, como comumente ocorre com alguns seres quando feridos. Mas não foi preciso muito esforço de minha parte, independentemente de nossas ações, em segundos, o passarinho foi-se debatendo e apagou de vez.

Não posso descrever a incredulidade dos olhos de uma criança de cinco anos de idade quando se deu conta daquela realidade. Ela olhava para mim, olhava o bichinho imóvel, e tentava o que todos nós tentamos no nosso dia a dia de adultos: não saber concretamente da morte. Ele dormiu?, ela me perguntava, inquieta. Nalgum ponto de sua pequena consciência de menina, ela soube que presenciara algo grave, porém, creio que tentava fugir a esse saber. Acorde, preguiçoso, dizia. Acorde, preguiçoso, sua mamãe já vai chegar, repetia. Deixe-o, ele está morto, eu lhe disse. Como é morto, dinda?, ela desentendia, como é morto? Dorme e não se levanta nunca mais, resumi. Vamos dar comida para ele, ela insistia, chorando. Precisei arrancá-la de lá, pois a menina estava presa àquela experiência que hoje, na altura de seus dezesseis anos, sequer deve se lembrar. Ela não cessava o choro e eu não queria ter de explicar aos pais: sua filha acabou de presenciar o irrevogável da morte e não passa bem. Por isso, enganei-a, levando-a para uma doceria.

Esse pequeno núcleo de vida pode ser aprisionado numa das tantas narrativas ocidentais, pois ao lado de grandes temas - como o do amor, do ódio, da esperança, do crescimento, da dor, do medo, da liberdade, da busca de sentido e de conhecimento - a morte é um dos assuntos mais profícuos das artes e da literatura. E é também um dos seus grandes encantamentos: justamente por causa da não-possibilidade de escolha, morrer é o destino óbvio e natural de quem está vivo. "A vida não é de se brincar, porque em pleno dia se morre", escreveu Clarice Lispector em Uma aprendizagem ou O livro dos prazeres, num dos tantos registros inusitados que temos acerca não somente da gravidade, mas, sobretudo, do caráter inesperado da morte. Essa é a segunda assertividade da morte: não nos avisar de sua chegada, ser repentina. Talvez por isso, passamos de medrosos e supersticiosos - aqueles que jamais mencionam a morte - a negativos e/ou melancólicos - que costumam cultuar a ideia do fim como traço de profundidade alternando com rasgos de poeticidade e sabedoria, quando tomamos Thanatos como um mote para reflexões sobre a origem e a natureza dialética dos seres humanos.

A terceira assertividade da morte é sua capacidade de provocar o fenômeno de ausência-presença de quem perdemos — sensação paradoxal a que em português 
chamamos graciosamente de saudade. Se as duas primeiras assertividades da morte acontecer irrevogavelmente e ser repentina - ocupam uma parte das representações literárias, é essa terceira que gera as produções mais dolorosas e encantadoras, tanto na prosa quanto na poesia.

Possuir o outro na ausência, e, não raras vezes, conscientizar-se de que somos parte desse outro justamente quando esse já não está: eis a saudade. Compreendemos tão profundamente essa dor que não nos parece absurdo Orfeu e Dante descerem ao reino dos mortos, atrás de Eurídice ou guiado por Beatriz, nem nos parecem desmedidas as súplicas de Camões pela intervenção de Dinamene, que já se encontrava no Paraíso. Ao contrário, se talento tivéssemos, faríamos o mesmo, pois adoramos e odiamos, a um só tempo, isso a que se definiu saudade. Não uma saudade temporária, mas a pior delas, a da perda, aquela provocada pelo rastro luminoso e encarnado da morte.

Não é incomum encontrarmos a associação entre amor e morte nas representações literárias, esse entrelaçamento aparece nos mitos, nas narrativas épicas e modernas, nas tragédias, nos dramas e nos poemas líricos. Dentro da diversidade de registros, a morte pode ser concebida como um processo natural, uma punição ou castigo, fuga da realidade, pretexto para incursões metafísicas e/ou sobrenaturais, índice de heroísmo ou mesmo como signo da condição trágica do ser humano. Entretanto, quando ligada ao amorpaixão, a morte, muitas vezes, funciona como um carrasco que põe fim à conexão mágica dos amantes.

Segundo Lúcia Castelo Branco (1985), a ameaça de Thanatos está presente desde a ideia da posse amorosa, pois essa sensação de que precisa ser dono absoluto do objeto amado traz o sentimento de ameaça constante ao enlace, e isso pode desaguar nas manifestações violentas ou crimes amorosos ou, ainda, no suicídio. Além de incorporar esse elemento fantasmagórico e ameaçador, as representações literárias lidam, há muito, com a metáfora encantatória de Thanatos, que paira sobre as descrições sexuais, simbolizando entrega, fusão e/ou orgasmo - também chamado, nalgumas culturas, de pequena morte dos parceiros. Mas é a perda do ser amado que mais tensiona Thanatos a assombrar os domínios de Eros, pois perder o grande amor é facilmente comparado à destruição ou danação de quem ama, e, não raras vezes, tirar a própria vida é visto como única opção do amante diante da perda do ser amado.

Preferir morrer na esperança de se juntar ao outro é uma tragicidade vivida na tradição de muitos pares, como ocorre com Evadne, em As suplicantes, de Eurípedes, que se mata por causa de Capaneu; o mito de Píramo e Tisbe, que inspira a lenda de Tristão e Isolda e a peça Romeu e Julieta, de Shakespeare; a desmedida de Simão e Teresa, em Amor de perdição, de Camilo Castelo Branco, ou, ainda, o solitário desespero de Werther, que se suicida por não ter a correspondência de sua idolatrada Charlotte. Nesse sentido, ora Thanatos está simbolizando uma concepção de amor além da vida, ora figura como uma saída para o sofrimento maior, que é o da perda ou impossibilidade se ter o ser amado. Em História do amor no Ocidente, Rougemont analisa o fascínio da cultura ocidental por essas histórias em que Eros e Thanatos entrelaçam-se, mostrando que a pulsão de morte não é o algoz que irá privar os amantes da sua esperança de felicidade, mas, antes, a última tentativa de superar os obstáculos intransponíveis da vida: cabe a Thanatos realizar, noutro espaço, noutro tempo, aquilo que Eros negou aos amantes.

A terceira assertividade da morte - presentificar o que já se foi, muitas vezes através da saudade, muitas vezes através de analogias - é o centro do romance de Filipa Melo. Ver, cheirar, tocar e conhecer o corpo sem vida do outro é uma via de mão dupla: descobre-se quem ali viveu, quem habitou aquele invólucro, através dos sinais do que já se desfez. O livro começa qual câmera que vai se abrindo gradativamente a nos mostrar 
a cristalização do fim no corpo de uma jovem mulher: "Quando o homem se aproximou da ponte, já o cão rodeava o corpo. Cheirava-o, roçando o focinho nas carnes, veias e ossos que pareciam triturados." (MELO, 2004, p.11).

Mas se não é a saudade o fio do novelo, é ainda do paradoxo da ausência-presença que a escritora se vale para, a partir da morte, reconstruir o perdido. O romance ocupa-se da morte através de sua materialidade: o corpo sem vida de Eduarda adquire uma positividade impressionante, suga toda a capacidade imaginativa dos vivos e, a partir desse recriar constante dos nossos sentidos frente ao perecível, o jovem corpo vai readquirindo signos de um outro existir. "Há quinze anos que lido com mortos. Que os corto, que os peso, que os viro do avesso para desvendar o seu mistério" (MELO, 2004, p. 20), nos diz o médico legista de Este é o meu corpo, num testemunho que nos remete à insistência de Eros, a ecoar aquilo que foi vida, de dentro dos domínios de Thanatos:

Vi corpos de velhos cobertos de crostas de sujo acumulado em anos de desmazelo. Com as unhas tão longas e rijas que pareciam de pedra, como garras que já não conseguiam usar para se defender. Vi corpos eletrocutados dentro de banheiras. Corpos com a traqueia corroída por ácidos ou desviada pela força de uma corda. Corpos tão comidos pela água do mar pelos caranguejos que, por vezes, só pelos dentes se conseguia identificar os seus donos. Vi corpos de crianças violadas com requintes de perversão. Corpos perfurados por balas, rasgados por facas, raspados, arrastados, espancados. Vi corpos, muitos corpos. E todos clamavam por justiça. (MELO, 2004, p.20).

A passagem nos traz uma lufada desse paradoxo: quem está morto clama por justiça. Um clamor que, evidentemente, liga a morte, através do horror e do caos de sua matéria, novamente à vida, à sobrevivência. Os que ficam e podem sentir os signos de Thanatos vão reconstruindo o que decepou aquela vitalidade e, com isso, fazem viver aquilo que é sombra. Dessa forma, o descuidado, a fatalidade, os acidentes, a violência, tudo se reorganiza para falar de uma força outrora viva. O personagem do médico legista, atento a esse processo, refaz sua percepção e nos afirma justamente o imorrível de cada criatura: "Hoje sei que quando os corto, os peso, os viro do avesso, são eles que me usam, e não o contrário. São eles que me chamam para falarem através de mim. É para isso que os mortos usam os corpos. Oferecem-nos, exibem-nos como prova." (2004, p.20).

Maurice Blanchot, em seus textos sobre literatura, história e morte, nos fala da recusa humana em aceitar a irrevogabilidade da morte, a nossa busca incessante de sobreviver, todos os dias, não apenas à morte de sentimentos, ideais, sonhos, pessoas, coisas, percepções, mas ao nosso próprio fim - físico, etéreo, anímico. O seu percurso, no entanto, não legitima essa rejeição humana da morte - mesmo quando consideramos o processo de rejeição como uma forma incansável de reconstrução do que foi perdido. $\mathrm{Na}$ verdade, Blanchot procura entender essa relação complexa na precariedade da linguagem literária que, esteticamente, reabre as fissuras do que morre no intuito de tornálo outra vez presente e, portanto, imortal.

Mas a relação de fascínio do texto literário não se esgota aí, pois na teimosia em fazer viver o que se foi, há um subtexto em toda linguagem artística que está permanentemente apontando para o impossível da morte: morrermos sem morrer. Isto é, ao escrever a morte, continuamos a existir, porque todo o universo se recusa ao ponto final e, se acaso ele viesse, não teríamos poder para grafá-lo. Dito de outro modo, se grafamos um ponto e o chamamos de final, é porque prosseguimos, e, inacabados, 
estamos a nos recontar, machadianamente, tal qual Brás Cubas, ou como o Quincas Borba, de Jorge Amado, ou, mais modestamente, como eu mesma ousei fazer no meu romance Henrique, no qual o protagonista, em estado de coma, insiste em narrar sua trajetória, buscando prolongar-se através da memória dos acontecimentos cruciais de sua vida.

Os exemplos acima servem como rubrica para o entendimento do espaço literário enquanto morada especial das interrogações ad infinitum da morte - a morte do próprio autor, dos outros ao seu redor, dos sentimentos, dos valores, dos símbolos, das culturas, dos tantos mundos que conhecemos e daqueles que apenas imaginamos. $\mathrm{E}$ isso permite figurações que rompem a simplória relação da morte com seu aspecto biológico, embora não estejam ausentes da pauta literária também os aspectos materiais e sociológicos dela, como ocorre em As intermitências da morte, de José Saramago, que, tomando como mote uma das Viagens de Gulliver, de Jonathan Swift - quando o viajante encontra uma ilha cujo povo é imortal —, descarta as consequências metafísicas, espirituais, afetivas e existenciais subjacentes à ideia da suspensão da morte humana, concentrando-se em mostrar o caos originado nas esferas institucionais, como igreja, estado etc. (tratados na primeira parte do livro), bem como as perversões do comportamento humano (tratados na segunda etapa). Contudo, a solução dada pelo romancista português ao pandemônio causado pela ausência da morte é, também, uma saída prevista pelo saber mítico, em que Eros volta a ecoar em Thanatos: a morte é personificada na forma de uma mulher e experimenta a complexidade do amor, o sentimento considerado mais nobre pela maioria dos humanos

"Não representamos porque queremos e quando queremos, mas o fazemos como maneira de nos tornarmos visíveis e ter o outro como visível", resume Costa Lima em Representação social e mimesis $(2015, \mathrm{~s} / \mathrm{p})$. Nesse sentido, imaginar realidades em que a discussão sobre a morte verticalize ou horizontalize nossa capacidade de lidar com ela permite ampliar nossa vivência trágica através da linguagem poética. A literatura, enquanto universo que tende a um jogo de recorte e ficicionalização da realidade, impõe cortes nos referentes, bifurcações nos significados, encenações e multiplicações de performances, manipulações e novas criações de referencialidades, que resultam não apenas em excesso de realidades ou complementos, mas também em crítica ao nosso próprio desejo de representar. Segundo João Adolfo Hansen, o mais interessante no conceito da mimese é seu deslizamento: "Quando se fala em mímesis, sabe-se muito bem do que se trata, mas não o quê" (1999, p.184). Nesse deslizar que nos impede de fixar a representação num único conceito ou procedimento, podemos encontrar elementos que negam aquilo mesmo que ali se representa, numa brincadeira infinita de desmentir as certezas alcançadas, a fim de jamais perder o devir e o prazer de organizar e desorganizar o mundo - eis a vertigem da escrita. Esse prazer de construção também desconstrói, pois a escrita é irônica, uma vez que coloca em dúvida o que se pré-concebia como real. Em outras palavras, manipular realidades possíveis não implica copiar seus referentes imediatos, espelhando-os, e, sim, jogar no espaço tenso entre fato e cena (máscara), Eros e Thanatos.

Não deixa de ser curioso, portanto, que o personagem de Filipa Melo seja legista, um profissional que precisa responder à pergunta crucial dos corpos sem vida que chegam às suas mãos: qual a causa de sua morte? Ele é um mediador entre dois mundos: aquele que vai palmilhar os signos dos mortos, que vai ouvi-los além-túmulo, para expor as causas do falecimento. Interrogando signo a signo, recolhendo indícios, examinando-os, dissecando-os, ele assentará lógica a tudo que grita de forma absurda na matéria incompreensível da vida. Da superfície da matéria — "Este é o corpo de um indivíduo 
branco do sexo feminino, bem constituído, um metro e setenta de altura e o peso aproximado de sessenta e cinco quilos. Está nu". (MELO, 2014, p.45) —, o autopsista vai mergulhando na verticalidade de quem outrora habitou tal espaço, vai colhendo dados e ligando-os ao que já antes pulsava:

As mãos e os dedos, longos. As unhas, roídas.

Os onicófagos são mais frequentes do que possas pensar. Pertences a um grupo extenso de roedores de si próprios. Comedores de si mesmos. Nunca fui tentado a roer unhas, não sei por que estranho impulso tu o fazias. Desejos autofágicos. Nervoso miudinho. O hábito, geralmente iniciado na infância, se não é rejeitado na adolescência, costuma manter-se durante toda a vida. [...] (MELO, 2004, p.50).

A transformação é gradual, vai se aprofundando à medida que a autopsia nos permite ler o corpo do morto. De "indivíduo do sexo feminino", esse passa a ser o corpo de uma mulher onicófaga, isto é, nos explica o médico, alguém que tem a estranha mania de querer devorar a si mesmo. Tal informação é uma das primeiras lacunas preenchidas, um dos primeiros signos a nos dizer algo concreto daquela desconhecida: "Sorrio. Os onicófagos possuem gestos particulares. Fogem a mostrar a unhas. Escondem-nas cruzando os braços e enfiando as mãos debaixo das axilas. Assentam o cotovelo e colocam uma das mãos, ou as duas, sobre o rosto, com os punhos fechados, as unhas apoiadas nas palmas. (2004, p.50).”

Assim como o legista, também nos perguntamos: então ela era assim? Agia assim? Não mais estamos diante de um indivíduo do sexo feminino, pois todas as pessoas que roem as unhas (inclusive eu mesma) nos fornecem, neste momento, imagens e gestuais que facilmente podemos colar à desse corpo em processo de emersão ou de narratividade. A partir daí, a morta renasce e é dentro dessa atmosfera de recriação e suspense que, mais à frente, sabemos de mais um fato antes de seu falecimento:

Escuto agora os teus gritos dentro do teu corpo. Escuto a morte na voz dos teus órgãos, que gritam, derrotados, aquilo que queres que eu oiça. São claros os teus recados. Morreste, mataram-te. Aguardas apenas o final da partida. O fim desse jogo insólito ao qual me dedico, suplicando-te.

Examino a superfície externa e abro a bexiga, da qual recolhera já amostra de líquido, através de punção directa com agulha e seringa. Registro o estado da superfície interna.

Prossigo.

E, enquanto executo o exame dos teus órgãos sexuais, ovários, útero e vagina, relembro o volume do teu ventre e dos teus seios, a pigmentação da aréola mamilar. Trago à memória as suspeitas e confirmo-as: os sinais de parto recente são evidentes. Anoto: Colo uterino com $6,8 \mathrm{~cm}$. Corrimento vaginal seroso e róseo. Provável uso de forceps. Episiotomia em vias de cicatrização. Peso do útero: 700 g. Parto ocorrido 6 a 7 dias do óbito. (MELO, 2014, p.90).

O bisturi do legista devassa e reconstrói esse assassinato, carregando-o de detalhes, interrogações, sustos, revoltas, curiosidades, montando o quebra-cabeças junto a outros pequenos núcleos dramáticos que a escritora intercala à evolução da autopsia da mulher desconhecida. Mas assim como Blanchot atenta para o fato de que nem a literatura nem a morte podem ser realmente esclarecidas, a lenta dissecação do corpo da jovem 
morta parece que, a qualquer momento, nos elucidará o obscuro dessa morte, contudo, "as palavras não querem dizer nada. As palavras não chegam", confessa-nos o médico diante da onicófaga: "Eu só tenho as palavras. São elas que, neste momento, te transformam em apenas mais um corpo. Que te reduzem ao mistério". (p.90).

O mistério é redutor porque está a fechar o círculo que começou pela superfície de um indivíduo do sexo feminino encontrado morto, foi se transformando numa mulher onicófaga, com hábitos e delineamentos próprios, uma mulher que lutou contra a morte, que retém as marcas de uma asfixia sofrida, que pariu outro ser alguns dias antes de morrer, que se chama Eduarda, que foi assassinada por Jacinto, todavia, é também uma mulher que volta a ser enigma: "Desconheço-te. Diz-me. Sei porque morreste, não sei porque viveste", apela o legista à página 94. A morte continua impossível e intangível porque, mesmo quando dissecada, o máximo que se pode saber são suas causas físicas. Seu mistério, entretanto, permanece, tensionando a obscuridade da vida.

O legista pede, suplica por palavras à morta. Representar e, assim, dissecar a morte seria uma forma de se desviar do limite a que se chegou: um limite onde a clareza se perde e o mistério retorna. A autopsia termina e não elucida, mas, antes, multiplica a morte e a vida que aquele corpo deixou para trás. Onde uma cessa e onde a outra começa é o eco que Este é o meu corpo expande, através da montagem do enredo e da alternância de narrador, ora em primeira, ora em terceira pessoa.

Dentro da atmosfera trágica e poética deste romance, nos soa irônico o anúncio no cemitério, que veta o uso de flores artificiais. O olhar do narrador, agora em terceira pessoa, se prende às diferenças entre como nós, humanos, vemos a morte e como se dá aquilo que se imagina ser a relação dos animais com a morte. Pesando prós e contras dessas duas diferentes relações — a dos seres humanos e a dos bichos —, a câmera do narrador vai se afastando dos personagens a fim de registrar o acento desnecessário na frase "são proibídas as flores artificiais".

O romance se encerra com a percepção desse erro, deixando em aberto, para que pensemos, pesemos, dissequemos, a razão por que se proíbe num cemitério o uso de flores artificiais. Será por que essas não morrem? Por que são um simulacro? Será por que são justamente o contrário das flores naturais, cuja existência é atravessada pelos signos doces-trágicos da beleza breve, da beleza que rapidamente perece? Seria um desrespeito dar a quem morre flores imorríveis? Ou se trata de uma posição estética lançada em letreiro, afinal, flores artificiais, lembremos, são geralmente feias de doer e abarrotariam o cemitério, afetaria a natureza, com sua não-perecibilidade?

Pode ser tudo isso e mais algo que nos escapou. Ou pode não ser nada disso, mas alguma coisa que vamos descobrir noutro encontro com Este é o meu corpo. Esse letreiro no final é mais uma das lacunas com que Filipa Melo trabalha, e, por analogia, podemos sentir sua seta apontando para esse conscientizar-se de lugares onde restamos emudecidos, como diante da ambiguidade ou paradoxo da morte.

De modo igual ocorre com o trabalho literário que, quanto mais incorpora as latências de Eros e Thanatos, menos as pode alcançar, embora não consiga deixar de ouvir a necessidade de dar forma a essas latências. Se o legista corta, pesa, analisa, disseca o corpo de Eduarda, mas não extrai dela a resposta capaz de esclarecer seu mistério, é também ele uma metáfora da figura do escritor ou da própria dinâmica da linguagem, a devassar os polos cada vez mais borrados de vida e morte sem, contudo, fazê-los falar de forma definitiva, uma vez que são, paradoxalmente, plenos de palavras e vazios de sentidos finais. 


\section{REFERÊNCIAS}

ALIGHIERI, Dante. A divina comédia. Trad. Ítalo Eugenio Mauro. São Paulo: 34, 1998. ARIÉS, Phillipe. História da morte no Ocidente. Trad. Priscila Vianna de Siqueira. São Paulo: Saraiva/Ediouro, 2012.

AUERBACH, Erich. Mimesis: a representação da realidade na literatura ocidental. Tradução George Berbard Sperder. São Paulo: Perspectiva, 1976.

BARTHES, Roland. O prazer do texto. Trad. J. Guinsburg. São Paulo: Perspectiva, 1977. BARTHES, Roland. Aula. Trad. Leyla Perrone Moisés. São Paulo: Cultrix, 1980.

BRANDÃO, Junito de Souza. Dicionário Mítico-Etimológico da Mitologia Grega. Vol. III. 1995.

BLANCHOT, Maurice. O espaço literário. Trad. Álvaro Cabral. Rio de Janeiro: Rocco, 1987.

BLANCHOT, Maurice. A parte dofogo. Trad. Ana Maria Scherer. Rio de Janeiro: Rocco, 1997.

BLANCHOT, Maurice. O livro por vir. Trad. Leyla Perrone-Moisés. São Paulo: Martins Fontes, 2005.

BRANCO, Camilo Castelo. Amor de perdição. Col. Clássicos da Literatura Portuguesa. Porto: Porto Editora, 2006.

BRANCO, Lucia Castello. Eros travestido: um estudo do erotismo no realismo burguês. Belo Horizonte: Editora da UFMG, 1985.

CAMÕES, Luiz Vaz de. Lírica I, II e III. Lisboa: Casa da Moeda, 1980.

CARVALHO, Olavo de. Aristóteles em nova perspectiva. Introdução à teoria dos quatro discursos. São Paulo: É Realizações, 2006.

D'ONOFRIO, Salvatore. Dicionário básico de cultura - o saber indispensável, os mitos eternos. Rio de Janeiro: Publit, 2009.

EVSLIN, Bernard. Heróis, deuses e monstros da mitologia grega.Trad. Marcelo Mendes. São Paulo: Arx, 2004.

FREUD, Sigmund. O mal-estar da civilização. Trad. Jayme Salomão. In:Obras completas. Rio de Janeiro: Imago, 1976.

FREUD, Sigmund. Além do princípio do prazer. Trad. Jayme Salomão In: Obras Completas. V.II. Versão em CD-ROM.

GOETHE, Os Sofrimentos do jovem Werther. São Paulo: Martin Claret, 2009.

HANSEN, João Adolfo. Estranhando a semelhança. In: GUMBRECHT, Hans Ulrich, ROCHA, João Cezar de Castro (org.). Máscaras da mímesis. Rio de Janeiro: Record, 1999. Pp. 179-199.

HESÍODO. Teogonia. Trad. Jaa Torrano. São Paulo: Iluminuras, 1995.

LEILLA, Állex. Henrique. Salvador: Domínio Públicco, 2001.

LIMA, Dayane Rouse Fraga. Este é o meu corpo que é dado por vós: sacrifício e redenção na obra de Filipa Melo. Revista Intersemiose, n.7, ano IV, pp. 15-31. Disponível em:

<http://www.neliufpe.com.br/wp-content/uploads/2015/10/021.pdf > Acesso em 18/02/2018.

LIMA, Luiz Costa. Representação social e mimesis (versão on line). Disponível em: <http://paginas.terra.com.br/arte/dubitoergosum/arquivo22.htm>. Acesso em:

25/03/2018. (essa versão não é paginada).

LISPECTOR, Clarice. Uma aprendizagem ou o livro dos prazeres. São Paulo: Ática, 1989.

MELO, Filipa. Este é o meu corpo. São Paulo: Planeta, 2004. 
MELO, Filipa. Os últimos marinheiros. Lisboa: Fundação Francisco Manuel dos Santos, 2015.

MELO, Filipa. Dicionário sentimental do adultério. Lisboa: Quetzal, 2017.

OVÍDIO. A arte de amar. Trad. David Jardim Jr. Rio de Janeiro: Ediouro, s/d.

OVÍDIO. As metamorfoses. Trad. David Jardim Jr. Rio de Janeiro: Ediouro, 1983.

PLATÃo. Banquete. In: Diálogos. Trad. José Cavalcante de Souza. São Paulo: Abril, 1972.

ROUGEMONT, Denis de. História do amor no Ocidente. Trad. Paulo Brandi e Ethel Brandi Cachapuz. Rio de Janeiro: Ediouro, 2002.

S/A. As mil e uma noites. Trad. Paulo Bazaglia. São Paulo: Paulus, 2014.

SARAMAGO, José. As intermitências da morte. São Paulo: Companhia das Letras, 2005. SPONVILLE, André-Comte. Pequeno tratado das grandes virtudes. Trad. de Eduardo Brandão. São Paulo: Martins Fontes, São Paulo, 1999.

SWIFT, Jonathan. As viagens de Gulliver. Trad. Therezinha Monteiro Deutsch. São Paulo: Nova Cultura, 1996.

TELLES, Lygia Fagundes. Nada de novo na frente ocidental. In.: Invenção e memória. São Paulo: Companhia das Letras, 2009, pp.113-120.

VALDIVIA, Olivia B. A Linguagem Interminável dos Amores. Jornal do Federal, n. 34, 1993.

VERNANT, Pierre. O universo, os deuses, os homens. Trad. Rosa Freire D'Aguiar. São Paulo: Companhia das Letras, 2000.

VIEIRA, Padre Antônio. Sermões. Porto Alegre: Edelbra, 1998.

WATT, Ian. Mitos do individualismo moderno. Trad. Mario Pontes. Rio de Janeiro: Jorge Zahar Editor, 1996. 